Paul Blackledge

\title{
Alasdair MacIntyre's Contribution to Marxism: A Road not Taken
}

\begin{abstract}
This essay questions, through a critique of his reading of classical Marxism, the path taken by Alasdair MacIntyre since his break with the Marxist Left in the 1960s. It argues that MacIntyre was uncharitable in his criticisms of Marxism, or at least in his conflation of the most powerful aspects of the classical Marxist tradition with the crudities of Kautskyian and Stalinist materialism. Contra MacIntyre, this essay locates in the writings of the revolutionary Left which briefly flourished up to and just after the Russian Revolution a rich source of dialectical thinking on the relationship between structure and agency that escapes the twin errors of crude materialism or political voluntarism. Moreover, it suggests that by reaching back to themes reminiscent of the young Marx this tradition laid the basis for a renewed ethical Marxism, and that in his youth MacIntyre pointed to the realisation of this project.
\end{abstract}

\section{Introduction}

"Dialectical idealism is closer to intelligent [dialectical] materialism than metaphysical, undeveloped, dead, crude, rigid materialism."

(Lenin 1961b, 274)

Since his break with the Marxist Left four decades ago, Alasdair MacIntyre has argued that while the young Marx aimed at understanding how "reasoning, especially practical reasoning, [gave] expression to forms of social practice" (MacIntyre 1994, 35), the older Marx came to embrace a form of mechanical materialism represented by the base-superstructure metaphor. Thus, in 1968, MacIntyre claimed that in his mature writings Marx understood the economic base and the political and ideological superstructure as standing "in external, contingent, causal relationship to each other". Repeating this claim in 1995, he suggested that this reified way of conceptualising the relationship between politics, economics, ideology and so forth reflected the extent to which Marx's thought was "distorted in a characteristically bürgerlich manner" (MacIntyre 1995a, 136-137; xviii; 1970, 60-61).

One consequence of this error was that Marx failed to register as a problem, and therefore did not see the need to analyse, the ethical dimension of workingclass agency. On the contrary, he combined an assumed but undeveloped variant of an Aristotelian virtue ethics with empirical observations of the class struggle 
between the bourgeoisie and the proletariat, to deduce that proletarian agency would foster a virtuous alternative to capitalism. Discussing this deduction in his essay "The Theses on Feuerbach: A Road Not Taken" (1994), MacIntyre argues that, by contrast with Marx's expectations to the contrary, the process of proletarianisation has simultaneously made resistance a necessary part of the lives of the working class, while robbing that resistance of those characteristics which might underpin a virtuous alternative to capitalism (MacIntyre 1998b, 232). He claims, consequently, that Marx's wager on the proletariat cannot today be justified, and that had Marx developed the implicit Aristotelianism of his early concept of working-class practice he might have recognised the limitations of this practice, and, thus, the utopian nature of his own political optimism. MacIntyre suggests that it was Lenin who most cogently recognised the limitations of proletarian practice, and it was this that led him to argue that workers could not create socialism under their own impetus and must therefore be led by bourgeois intellectuals: "What resulted", MacIntyre notes, "scarcely needs comment" (MacIntyre 1985b, 247).

If a variant of this argument informed MacIntyre's break with the Marxist Left in the 1960s, his articulation of the concept of social practices in After Virtue and elsewhere can be read as an attempt to complete a project begun by Marx in 1845 but discarded thereafter: the search for those forms of practice that might underpin a virtuous alternative to capitalism. Indeed, Kelvin Knight has argued that while MacIntyre has never "abandoned Marx's idea of revolutionary practice", he has abandoned "the Marxism of the Second, Third and Fourth Internationals', including the Leninist understanding of revolution as an event to be effected by a small community of cadres, using the working class as their instrument" (Knight 2007, 122).

In this essay, I challenge this reading of classical Marxism with a view to suggesting a re-appraisal of MacIntyre's early Marxist writings. As MacIntyre himself once pointed out, Marx's base-superstructure metaphor need not be interpreted as a variant of mechanical materialism (MacIntyre 1998a), and while it came to be interpreted in such a way by both Kautsky (at his worse, cf. Blackledge 2006b) and by Stalin, the insights of the young Marx were renewed by the revolutionary Left of the Second and Third Internationals in the all too brief moment between the lead up to 1917 and the Stalinist counter-revolution. In this essay I examine the process through which sections of the revolutionary Left in this period decisively broke with mechanical materialism. I suggest that it was MacIntyre himself who pointed to the consummation of this project in the 1950s, and that it is a minor political tragedy that he did not develop his early insights in this direction.

\section{Towards an Ethical Marxism: Lenin, Lukács and Gross- man}

In "Rights, Practices and Marxism" (1985), MacIntyre wrote, fairly conventionally of Lenin, that unlike Marx he recognised that because the working class did 
not have the moral resources necessary to construct a socialist future he revised Marxism to become the ghost in the machine, offering leadership to the working class through the socialist intelligentsia (MacIntyre 1985b, 247). By this route, as he argued in After Virtue, in conditions of moral impoverishment, Marxists were wont to construct their own "versions of the Ubermensch": "Lukács's ideal proletarian" or "Leninism's ideal revolutionary" for instance (MacIntyre 1985a, 261-262).

Despite the widespread acceptance of something like this interpretation of Lenin's politics, it is simply not the case that he believed that that the working class was too morally impoverished to lead a socialist revolution. Rather, as a socialist intellectual, his efforts were focused on what he could do to advance the workers' struggles. For instance, in an early critique of the 'egal Marxist' Peter Struve, he argued that, while it was a weakness with traditional moral theory that it failed "to connect its 'ideals' with any immediate interests", Struve ran the "risk of becoming an apologist" for the status quo because he erred in the opposite direction by reducing materialism to its objectivist caricature. In opposition to both moral subjectivism and economic objectivism, Lenin suggested that materialism, because it examined the contradictions of any social process, "includes partisanship ... and enjoins the direct and open adoption of the standpoint of a definite social group in any assessment of events" (Lenin 1960, 400-401). The break with any form of dualism between science and morality that is implicit to this argument, was subsequently reinforced through Lenin's attempt to realise the project of What is to be Done? (Lenin 1961a).

It is one of history's ironies that a core constituent of the myth of Leninism, constructed by the Stalinists from the mid-1920s onwards to justify their own power and accepted by Western liberal intellectuals thereafter for their own ideological reasons, includes a key constituent part of the Bersteinian revisionism which Lenin fought from the outset: what Mészáros calls Bernstein's "patronizing treatment of the working classes" (Mészáros 1995, 4). According to Lars Lih in his definitive study of What is to be Done?, in the 'textbook interpretation' of Leninism, Lenin's contempt for the intellectual capacities of workers was reflected in his insistence on building a party of professional revolutionaries who would bring socialist ideas to the working class from without and subsequently lead this class in a top-down manner. By contrast with this myth, Lih shows that Lenin's underlying assumption in What is to Be Done? was an optimism about the possibility of the growth of socialist consciousness within the Russian working class, combined with scathing criticisms of the weaknesses of Russia's radical intelligentsia generally and the Russian socialist movement specifically, which, he claimed, were in grave danger of failing the workers' movement in the coming revolution (Lih 2006, 27; 615; cf. Blackledge 2006a).

Concretely, Lenin polemicised against the re-emergence of economism within Russian social democracy - the local variant of Bernsteinian reformism. A crucial constituent part of Bernstein's revisionism included a rejection of what he believed to be Marxism's romanticisation of the working class. Against Marx, Bernstein claimed that the working class was "not yet sufficiently developed to take over political power", and that the only people who disagreed with this 
prognosis were those pseudo-revolutionaries "who have never had any close relationship with the real labour movement" (Bernstein 1993, 206). Similarly, the Russian 'economist' Krichevski accused the Iskra group of "being over-optimistic about the possibility of proletarian awareness and organisation", and insisted that workers were interested only in basic bread and butter issues, not socialist politics. Against Krichevski, Lenin argued in Lih's paraphrase, that "worker militancy is not the problem because it is increasing in leaps and bounds all on its own. The problem, the weak link, is effective party leadership of all this militancy" (Lih 2006, 316-317). Indeed, Lenin suggested that socialists who spoke only of bread and butter issues to workers both patronised them whilst simultaneously failing to challenge the hegemony of bourgeois ideology within the working class (226).

Unfortunately, as is widely known, in so far as Lenin theorised this position he borrowed concepts from Kautsky who insisted that "socialist consciousness is something introduced into the proletarian class struggle from without" (Lenin 1961a, 384, 375). Given the preponderance of crude nonsense written about this argument, two points are worth stressing. First, the relationship between spontaneity and consciousness is not the central thesis of What is to be Done? Rather, Lenin's discussion of this point was hurriedly added to the text as a response to Krichevski's discussion of the relationship between spontaneous movements and conscious leadership in an article published as Lenin was writing What is to be Done? Second, understood in the context noted above it is clear, as Lih points out, that on this issue Lenin meant the opposite of what he typically taken as meaning. It was his opponents who dismissed the socialist potential of working-class struggle, whereas he defended it.

Elsewhere Lenin did address the question of the relationship between socialism and the movement from below in terms which both confirm Lih's interpretation of that text and which point to his developing break with Second International dualism (cf. Cliff 1986, 81; Lenin 1962, 32). Indeed, whereas Kautsky famously wrote that "social democracy is a revolutionary party, but it is not a party that makes revolution" (Kautsky, in Salvadori 1979, 40), for Lenin the party "would not sit round waiting for the call to insurrection, but would carry out such regular activity that would guarantee the highest probability of success in the event of an insurrection" (Lenin, in: Harman 1996, 31).

If the gap between Lenin and Kautsky was only implicit before 1914, the shock of war and Lenin's subsequent reading of Hegel made his split with his former teacher explicit and absolute. In notes taken from a close reading of Hegel's Science of Logic he expressed his break with dualism thus: "The activity of man, who has made an objective picture of the world for himself, changes external actuality, abolishes its determinates (= alters some sides or other, qualities of it), thus removes from it the features of semblance, externality and nullity, and makes it as being in and for itself (=objectively true)" (Lenin 1961b, 217218). Commenting on these notebooks, Stathis Kouvelakis points out that it is "particularly significant that Lenin ended the section on "philosophical materialism" with a reference to the notion of "revolutionary practical activity'". For Lenin understood subjective practical activity to be at the centre of the "ob- 
jective" world, and consequently insisted that social scientific laws should not be "fetishised" as things distinct from conscious human activity but instead be recognised as necessarily "narrow, incomplete, [and] approximate" attempts to frame political intervention (Kouvelakis 2007, 174, 186). Consequently, whereas Second International theorists had interpreted Hegel's claim that to act freely meant to act in accordance with necessity in a reductive manner, for Lenin, as Day argues, "man's consciousness not only reflects the objective world but creates it" (Day, in: Anderson 1995, 113). In fact, as Callinicos argues, it was because Lenin was unsure about the future that he acted with the intention of influencing the course of history: his activism was rooted in his belief that "the very unpredictability of history requires that we intervene to help shape it" (Callinicos 2007, 26).

Commenting on Lenin's overall political trajectory, Lukács argued that "the development which Marxism thus underwent through Lenin consists merelymerely! - in its increasing grasp of the intimate, visible, and momentous connexion between individual actions and general destiny - the revolutionary destiny of the whole working class" (Lukács 1970, 13). If Lenin's praxis led him to a break with Kautskyism, it was in part because, as he argued, "practice is higher than (theoretical) Knowledge" (Lenin 1961b, 213). Nevertheless, the break with the Second International had to be theorised, and while Lenin, in State and Revolution, went back to Marx and Engels' criticisms of the Gotha and Erfurt programmes to argue that the key political error of Kautskyism was its strategic orientation towards the state, Lukács' History and Class Consciousness magnificently articulated this break at a philosophical level.

According to Martin Jay, Lukács' History and Class Consciousness "can be seen as the most articulate expression on a theoretical level of the world-historical events of 1917" (Jay 1984, 103). More specifically, Arato and Breines point out that within this book Lukács developed a "powerful critique of Kantian ethics" (Arato/Breines 1979, 126). Indeed, Lukács' book includes a criticism of Kant's concept of the thing-in-itself, which, he argued, underpinned the antinomies of his philosophy by acting as a limit to human knowledge of the world. Moreover, Lukács claimed that this element of Kant's philosophy was characteristic of bourgeois social theory more generally - that is theory from the standpoint of civil society - which could not escape the antinomies between, for instance, freedom and necessity, fact and value, form and content, and subject and object (Jay 1984, 110). These antinomies, Lukács suggested, were reproduced within Second International Marxism, and their transcendence became a possibility only with the rediscovery of the living concept of the totality associated with Lenin's return to Marx (Lukács 1970). Concretely, Lukács insisted that the totality can only be conceived from the standpoint of a social class (Lukács 1971, 28). More specifically, it is only with the rise of capitalism, that is with the break with the last vestiges of the natural economy, that it becomes possible to conceptualise society as a totality, and of the two central classes of modern capitalism, only the proletariat is able to conceive the totality as a historical form. Marxism, as the scientific understanding of capitalist society, emerged and could have only emerged from the standpoint of the practice of the proletariat. Indeed, whereas Kant had 
argued that the essence of the world, the thing-in-itself, remained shrouded in mystery, Lukács countered that at its essence capitalism was a system of generalised commodity production within which, fundamentally, human labour-power was a commodity. The emergence of proletarian class-consciousness thus coincided with the growing self-consciousness of the capitalist mode of production as a totality: the proletariat could potentially become the "unmediated consciousness of the commodity" (Lukács 1971, 173). Conversely, while the bourgeoisie, like the proletariat existed as global class, it was unable to conceive capitalism as a totality because of the structurally competitive relations between its individual members. Human liberation could only come from a global class, and the bourgeoisie, unlike the proletariat, was incapable of playing this role because, while it was global, it was also necessarily fragmented.

Lukács' deployed the concept of "imputed class consciousness" to describe the relationship of Marxism to the actual political consciousness of the working class. MacIntyre, like others of his critics have often pointed to this concept to suggest that while Lukács aimed to overcome the dualism characteristic of Second International theory, in practice he failed to conceptualise the movement towards class consciousness within the working class except as an epiphenomena of a mythical final collapse of capitalism (Stedman Jones 1977, 42). Against this argument, John Rees has pointed out that in both History and Class Consciousness, and in the recently discovered defence of that book, Tailism and the Dialectic, Lukács did indeed point to the process by which workers could develop class consciousness (Rees 2000, 28-32). In fact, Lukács insisted that the emergence of socialist consciousness within the working class "does not lie outside the real process of history. It does not have to be introduced into the world by philosophers" (Lukács 1971, 77). More specifically, he argued that the revolutionary party should not be understood as an elite group of intellectuals, but should rather be thought of as "that part of the proletariat that spontaneously rebels against its leaders' behaviour" (Lukács 1971, 289). More specifically, he suggested that "in no sense is it the party's role to impose any kind of abstract, cleverly devised tactics upon the masses. On the contrary, it must continuously learn from their struggle and their conduct of it. But it must remain active while it learns" (Lukács 1970, 36; cf. 1971, 331, 334). Consequently, for Lukács, as Michael Löwy has pointed out, "imputed' class consciousness is not a transcendental entity, an "absolute value" floating in the world of ideas: on the contrary, it assumes an historical, concrete and revolutionary shape - the Communist Party" (Löwy 2003, 183; cf. Rees 1998, 219-225; Lukács 2000, 63-86). Moreover, this model of revolutionary leadership is predicated upon the existence of a spontaneous socialist working-class movement from below, and by synthesising revolutionary leadership and the movement from below Lukács confronted full square Kautsky's dualism.

Commenting on Auer's famous letter to Bernstein which suggested a de facto reformist practice as a more efficient strategy for changing the party than Bernstein's frontal assault on the programme, Lukács claimed that Auer's proposed project had in practice been realised by Kautsky; for Kautsky deployed Marx's concepts, while simultaneously assuming a dualism between facts and values 
which effectively neutered Marxism by clinging to its vocabulary whilst jettisoning its practice (Lukács 1972, 133). More generally on the revisionist debate, Lukács claimed that Bernstein's embrace of Kantian moralism reflected not the transcendence of Second International fatalism, but its opposite side: it "is the subjective side of the missing category of totality" (Lukács 1971, 38). Indeed, while Lukács agreed with Kautsky's criticisms of the formalism of Kant's ethics (cf. Kautsky 1918), he pointed out that it was not enough to conclude that any moral imperatives derived from this perspective were an inadequate basis for socialist strategic thought. Rather Kant's ethical formalism pointed back to the methodological problem of his concept of the thing-in-itself which acted in his system as a fundamental limit to human knowledge of the world (Lukács 1971, 124-125). Thus the critique of Kant's ethical formalism should have pointed Kautsky back to the concept of the totality. That it did not reflected the way in which his dualism allowed him to talk revolution whilst abandoning the real practical leadership of the party to the reformists.

Lukács argued that whereas Kant assumed that social reality was a given, by showing that it was in fact a product of human history Hegel had pointed beyond this dualism, and by materialising Hegel's project Marx had overcome it. To separate free human actions from a necessarily given social world, as was done by the neo-Kantians, implied losing sight of the fact that both freedom and necessity existed in a dynamic relationship such that not only is the world a product of human actions, but the kind of people that we are is itself a product of history: in Parkinson's paraphrase "we are both producer and product of the historical process" (Parkinson 1977, 43). The consequence of this methodological movement was to unfreeze the concepts through which we aim to understand the world. As Jay argues, "Being would then be understood as Becoming, things would dissolve into processes, and most important of all, the subjective origin of those processes would become apparent to the identical subject-object of history" (Jay 1984, 111). Indeed, Lukács suggested, a key philosophical task "is to discover the principles by means of which it becomes possible in the first place for an 'ought' to modify existence. And it is just this that [Kant's] theory rules out from the start" (Lukács 1971, 161; cf. Arato/Breines 1979, 127).

Concretely, the aim of History and Class Consciousness was "to demonstrate methodologically that the organisation and tactics of Bolshevism are the only possible consequence of Marxism" (Lukács 2000, 47). Lukács argued, the structure of both the SPD specifically and the Second International more generally reflected their de facto reformism, while the Bolshevik Party, because it was built as a combat organisation, became the organisational embodiment of the Marxist transcendence of dualism: Lenin's aim was not to comment upon objective developments within the world but to shape such processes through praxis (Lukács 1971, 295-342).

Lukács suggested that two works were of fundamental importance to the renewal of Marxism out of the degeneration of the Second International orthodoxy: Lenin's State and Revolution and Rosa Luxemburg's The Accumulation of Capital (Lukács 1971, 34-35). According to Lukács, through his book Lenin completed his political break with Second International fatalism, while Luxemburg 
played a similar role in freeing Marx's economic theory from Second International Marxism. Luxemburg's study was intended as an extension of her earlier critique of Bernstein's rejection of the Marx's breakdown theory. Whereas Kautsky denied that Marx held to such a model, in Reform or Revolution Luxemburg argued that the contradictions of capitalism will progressively worsen "resulting inevitably, at some point, in its collapse" (Luxemburg 1989, 29). Similarly, in The Accumulation of Capital, she claimed that capitalism "must break down" and that at "a certain stage of development there will be no other way out than the application of socialist principles" (1951, 467). Whatever the undoubted merits of this argument, it is open to the criticism that by embracing a theory of breakdown Luxemburg did not actually succeed in theorising a break with Second International fatalism.

By contrast with this line of argument, Rick Kuhn has recently argued that the problem with Luxemburg's analysis of capitalism lay not in her embrace of a theory of breakdown, but the substantive arguments through which she defended this theory. Kuhn argues that it was to this problem that the early Frankfurt School Marxist, Henryk Grossman, applied himself in his classic The Law of Accumulation and the Breakdown of the Capitalist System (1929). Grossman claimed that Luxemburg's arguments failed because they were "not rooted in the immanent laws of the accumulation process, but in the transcendental fact of the absence of non-capitalist markets" (Grossman, in: Kuhn 2007, 126). In relation to Bernstein, Grossman insisted that he "was perfectly right in saying [... ] 'if the triumph of socialism were truly an immanent economic necessity, then it would have to be grounded in a proof of the inevitable economic breakdown of the present order of society"' (Grossman 1992, 39). By denying that Marx held to a theory of breakdown, Kautsky fatally damaged his critique of Bernstein by accepting his basic assumptions about the nature of capitalism. Grossman went on to say that it was Luxemburg's great contribution to the revisionist debate to return to Marx and defend the theory of breakdown. Unfortunately, because she shifted "the crucial problem of capitalism from the sphere of production to that of circulation" she undermined her own arguments. Moreover, she tended to conceive of the breakdown as a "mechanical" process, which consequently opened her defence of the theory to the charge of "fatalism" (1992, 41-42). Somewhat ironically, given this criticism of Luxemburg, in 1934 Grossman was criticised by Anton Pannekoek for apparently reducing Marxism to a form of mechanical materialism (Pannekoek 1977, 62). Actually Grossman followed Lenin in insisting that "there is no absolutely hopeless situation" for capital. He believed that a defensible theory of economic breakdown must be integrated into an adequate theory of political revolution. His goal was thus to overcome the problems with Luxemburg's defence of the theory of breakdown such that it could be developed as a theoretical basis for political action. Against political fatalism, he insisted that capitalist breakdown was not an automatic, mechanical process; whilst against political voluntarism he pointed out that an adequate theory of political practice must be rooted in an understanding of the crisis prone dynamic of the capitalist system. Consequently, as Kuhn explains, Grossman aimed to do for the Marxist approach to the critique of political economy what Lenin 
had done for politics and what Lukács had down for philosophy: to transcend Second International dualism through a dialectical approach to the relationship between freedom and necessity (Kuhn 2007, 125).

Concretely, Grossman insisted that Second International theorists had departed from Marx's theory of the law of the tendency of the rate of profit to fall. It was this secular tendency, he argued, itself rooted in the capital accumulation process, which condemned capitalism to recurrent crises. Following Marx's method of moving from the abstract to the concrete, Grossman opened his book with an abstract model of capitalism's tendency towards crisis. He then shifted to examine the countervailing tendencies which mediated against breakdown. Finally, in a section that is unfortunately absent from the English edition of his book, he examined the interaction between crises and class struggle. Arguing that no crisis is irresolvable so long as workers are prepared to pay the price, he pointed out that the class struggle would itself "shape the actual course of the system's tendency to break down" $(1992,135)$. Kuhn points out that Grossman took the British miners' strike of 1926 as an example of the dialectical relationship between economics and politics in a period of crisis: economic crisis set the scene for miners' lockout and the General Strike, but the actual outcome of these struggles and thus of the economic crisis itself was ultimately determined by the political struggle. Writing to Paul Mattick two years after the completion of his book, Grossman pointed out that his aim had been to show how "objective revolutionary situations arise", which inform the intensification of the class struggle, but which neither mechanically guarantee the victory of either side in these struggles, nor determine the outcome of the crisis itself: "The purpose of my breakdown theory was not to exclude this active intervention, but rather to show when and under what circumstances such an objectively given revolutionary situation can and does arise." (Grossman, in Kuhn 2007, 144)

\section{Revolutionary Ethics}

If Lenin, Lukács and Grossman all added to the renewal of Marxism through a break with Second International dualism, it is unfortunate that none of them made more than tentative comments on the ethical dimension of socialism. Nevertheless, two works were produced in this period which pointed towards a Marxist ethics: Evgeny Pashukanis's Law and Marxism (1924), and Leon Trotsky's "Their Moral and Ours" (1938).

According to Pashukanis there exists an intimate and necessary relationship between the emergence of the idea of individual equality and the system of generalised commodity production: "For the products of human labour to be able to relate to each other as values", he wrote, "it is necessary for people to relate to each other as autonomous and equal personalities" (Pashukanis 1978, 151). Indeed, Pashukanis insisted that three conditions must be satisfied for capital accumulation to become generalised: people must become "moral subjects", "legal subjects", and they must live their lives "egoistically". Corresponding to this situation, moral law, far from being a universal good, is best understood as 
the ideological form necessary to regulate the "intercourse between commodity owners". A consequence of the relationship between morality as the ideology of free action and capitalism as a system of social compulsion, Pashukanis argued that there is a necessary ambiguity in the moral law whereby, on the one hand, it presents itself as the rational basis for the actions of free individuals, while, on the other hand, it is a social law standing above individuals (Pashukanis 1978, 154). The only way to rid the moral law of this ambiguity, he claimed, is to eliminate capitalism through the creation of a planned economy. However, in so doing, the atomised nature of our present day individuality would be overcome, and so would the basis for the ethical form itself (158). Thus, just as the struggle for socialism involves a struggle against states and laws then it similarly involves the struggle against morality (160).

Trotsky's pamphlet Their Morals and Ours was written in a more concrete register than was Pashukanis' book, and as an explicit challenge to those for whom Marxism was a crude form of moral consequentialism, according to which "the ends justified the means". In opposition to such interpretations of Marxism, Trotsky first insisted that any adequate ethical theory must have an eye to the ends of action, as the alternative most fully expressed by Kant, could not survive without the idea of God, and thus represented a backwards step after Darwin (16-17). While Trotsky therefore argued that "a means can only be justified by its end", he also pointed out that "the end in its turn needs to be justified". He subsequently proceeded to offer two Marxist justifications of the end of revolutionary socialist action: first, "if it leads to increasing the power of humanity over nature and to the abolition of the power of one person over another"; second, which is really a variation on the first, "that is permissible [...] which really leads to the liberation of humanity" (48). Whereas the distance between this formulation and Bernstein's Neo-Kantianism is plain, it is less obvious that Trotsky's model escapes the charge of consequentialism. Nevertheless, Trotsky did insist that Marxism "does not know dualism between means and ends", and suggested a "dialectical independence" between the two. Thus he repeated Lassalle's suggestion that "a different path gives rise to a different goal". Moreover, he claimed that "not all means are permissible", and because "the liberation of the workers can only come through the workers themselves" then only those means are permissible "which unite the revolutionary proletariat". Indeed, any means which lowers the "faith of the masses in themselves", by, for instance, "replacing it by a worship for the "leaders"" is not permissible (49-51).

Whatever the shortcomings of this short pamphlet, Trotsky's argument certainly does not fit easily with the claim that Marxism is a form of dualism which posits itself as the ideology of the leaders who use the working class as an instrument in their struggle for state power. Moreover, against the claim that Trotsky simply regurgitated a form of consequentialism, John Dewey pointed out that Trotsky had in fact made an implicit differentiation between two types of ends: final ends and those ends which are themselves means to the final end. While Trotsky had not made this differentiation explicit in Their Morals and Ours, Dewey suggested that it would be a simple matter to so do. Moreover, if this were done then Trotsky could, quite rigorously, claim both to have defended the 
interdependence of means and ends, and to have provided an answer to those who argue that by positing only some distant end, consequentialism does not actually reflect on the observable short-term consequences of the means deployed to reach this end (Dewey 1973, 68-69). Nevertheless, despite these strengths, Dewey claimed that the force of Trotsky's position was weakened by what he perceived to be a dogmatic "deduction" of the claim that the agency of radical change would be the working class: "the selection of class struggle as a means", Dewey insists, has itself "to be justified" (1973, 70-71).

That workers' struggles might generate a real need for solidarity which could underpin emerging socialist virtues was, to my knowledge, never explicitly defended by any of the intellectuals discussed above, and the Stalinist counterrevolution ensured that it was not until the emergence of a New Left after 1956 that these problems re-emerged and a new generation began to look for answers to them.

\section{Conclusion}

Interestingly it was through the medium of the British New Left's debates on socialist humanism in the late 1950s that a young MacIntyre attempted to articulate a sophisticated Marxist justification for the ethical significance of workingclass practice (Blackledge 2005; 2006c; 2007). In "Notes from the Moral Wilderness" (1958-1959), he drew upon and extended Marx's claim, as made in the Economic and Philosophical Manuscripts (1844), that the separation of means from ends characteristic of production within bourgeois society might be overcome through workers' struggles (Marx 1975, 365). MacIntyre suggested that the proletariat, created objectively through the development of the forces of production, could begin in its struggles against capital to match the potential inherent in its objective structure and create the conditions for the solution of the contemporary problems of morality: it potentially begins to embody the practice which could overcome the "rift between our conception of morality and our conception of desire" (MacIntyre 1998a, 45). Indeed, by acting in this way workers come to realise that solidarity is not simply a useful means through which they struggle to meet their needs, but it is in fact what they naturally desire $(1998 \mathrm{a}, 48)$. With this argument MacIntyre suggested a final piece of the puzzle through which the renewal of Marxism, opened by the revolutionary break with Kautskyism and then crushed by the rise of Stalinism, could finally be completed.

That he subsequently came to accept the common assumption that Marxism be condemned by Marx's mature retreat towards a mechanical form of materialism rests upon a rather uncharitable reading both of his mature works and of the works of those revolutionaries who struggled against Kautskyism and Stalinism. If Marxism at its best escaped from the bourgeois antinomy between freedom and necessity then this suggests more space for a rapprochement between MacIntyre and Marxism than he would probably care to admit. Nevertheless, there remains the problem of the ethical significance of those communities created by workers 
in struggle. If it is beyond question that such communities exist, it remains the case that their ethical significance can only be judged by close empirical investigation. This, I contend, is an open question of the utmost relevance to ethical anti-capitalists. Consequently I think it an important intellectual error on MacIntyre's part to assert that "while proletarianisation makes it necessary for workers to resist, it also tends to deprive workers of those forms of practice through which they can discover conceptions of a good and of virtues adequate to the moral needs of resistance" (1998b, 232).

\section{Bibliography}

Anderson, K. (1995), Lenin, Hegel and Western Marxism, Chicago

Arato, A./Breines, P. (1979), The Young Lukács and the Origins of Western Marxism, London

Bernstein, E. (1993), The Preconditions of Socialism, Cambridge

Blackledge, P. (2005), Freedom, Desire and Revolution: Alasdair MacIntyre's Early Marxist Ethics, in: History of Political Thought 26(4), 696-720

- (2006a), What was Done: Lenin Rediscovered, in: International Socialism 111, $111-126$

- (2006b), Karl Kautsky and Marxist Historiography, in: Science and Society 70(3), $337-359$

- (2006c), The New Left's Renewal of Marxism, in: International Socialism 112, $125-153$

- (2007), Morality and Revolution: Ethical Debates in the British New Left, in: Critique 35(2), 203-220

Callinicos, A. (2007), Leninism in the Twenty-first Century?, in: Budgen, S. et al. (eds.), Lenin Reloaded: Towards a Politics of Truth, London, 18-41

Cliff, T. (1986), Lenin: Building the Party, London

Dewey, J. (1973), Means and Ends, in: Trotsky, L. et al., Their Morals and Ours, New York, $67-73$

Grossman, H. (1992), The Law of Accumulation and the Breakdown of the Capitalist System, London

Harman, C. (1996), Party and Class, in: Callinicos, A. et al., Party and Class, London, $15-37$

Jay, M. (1984), Marxism and Totality, Berkeley

Kautsky, K. (1918), Ethics and the Materialist Conception of History, Chicago

Knight, K. (2007), Aristotelian Philosophy: Ethics and Politics From Aristotle to MacIntyre, Cambridge

Kouvelakis, S. (2007), Lenin as Reader of Hegel, in: Budgen, S. et al. (eds.), Lenin Reloaded: Towards a Politics of Truth, London, 164-204

Kuhn, R. (2007), Henryk Grossman and the Recovery of Marxism, Chicago

Lenin, V. (1960), The Economic Content of Narodism, in: Collected Works 1, Moscow, 333-507

- (1961a), What is to be Done?, in: Collected Works 5, Moscow, 347-529

- (1961b), Philosophical Notebooks, in: Collected Works 38, Moscow

- (1962), The Reorganisation of the Party, in: Collected Works 10, Moscow, 29-39

Lih, L. (2006), Lenin Rediscovered: What is to be Done? In Context, Leiden

Löwy, M. (2003), The Theory of Revolution in the Young Marx, Leiden

Lukács, G. (1970), Lenin: A Study in the Unity of his Thought, London 
- (1971), History and Class Consciousness, London

- (1972), Bernstein's Triumph, in: G.Lukács, Political Writings 1919-1929, London, $127-133$

- (2000), Tailism and the Dialectic: A Defence of History and Class Consciousness, London

Luxemburg, R. (1951), The Accumulation of Capital, London

- (1989), Reform or Revolution, London

MacIntyre, A. (1970), Marcuse, London

- (1985a), After Virtue, London

- (1985b), Rights, Practices and Marxism, in: Analyse \& Kritik 7, 234-248

- (1994), Interview with Professor Alasdair MacIntyre, in: Kinesis 20, 34-47

- (1995), Marxism and Christianity, London

- (1998a), Notes from the Moral Wilderness, in: Knight, K. (ed.), The MacIntyre Reader, Cambridge, 31-49

- (1998b), The Theses on Feuerbach: A Road Not Taken, in: Knight, K. (ed.), The MacIntyre Reader, Cambridge, 223-234

Marx, K. (1975), Economic and Philosophical Manuscripts, in: Marx, K., Early Writings, Harmondsworth, 279-400

Mészáros, I. (1995), Beyond Capital, London

Pannekoek, A. (1977), The Theory of Capitalist Collapse, in: Capital and Class 1, $59-81$

Parkinson, G. H. R. (1977), Georg Lukács, London

Pashukanis, E. (1978), Law and Marxism, London

Rees, J. (1998), The Algebra of Revolution, London

- (2000), Introduction, in: G.Lukács, Tailism and the Dialectic: A Defence of History and Class Consciousness, London, 1-38

Salvadori, M. (1979), Karl Kautsky and the Socialist Revolution, London

Stedman Jones, G. (1977), The Marxism of the Early Lukács, in: New Left Review (ed.), Western Marxism: A Critical Reader, London, 11-60

Trotsky, L. (1973), Their Morals and Ours, in: Trotsky L. et al., Their Morals and Ours, New York, 13-52 